\title{
Microscopy and literature
}

\author{
Article
}

Accepted Version

Creative Commons: Attribution-Noncommercial-No Derivative Works 4.0

Harris, P. J. F. (2019) Microscopy and literature. Endeavour, 43 (3). 100695. ISSN 0160-9327 doi:

https://doi.org/10.1016/j.endeavour.2019.100695 Available at https://centaur.reading.ac.uk/87012/

It is advisable to refer to the publisher's version if you intend to cite from the work. See Guidance on citing.

To link to this article DOI: http://dx.doi.org/10.1016/j.endeavour.2019.100695

Publisher: Elsevier

All outputs in CentAUR are protected by Intellectual Property Rights law, including copyright law. Copyright and IPR is retained by the creators or other copyright holders. Terms and conditions for use of this material are defined in the End User Agreement.

\section{www.reading.ac.uk/centaur}

\section{CentAUR}

Central Archive at the University of Reading

Reading's research outputs online 


\section{Manuscript Details}

\section{Manuscript number}

Title

Article type
ENDE_2018_67

Microscopy and literature

Feature

\section{Abstract}

On the face of it "Microscopy and literature" would seem an unpromising subject for an article. It would certainly be misleading to suggest that microscopes and microscopy have played a major role in English or European literature. However, when one begins to research the subject, many examples of microscopy in literature can be found. There is little doubt, for example, that the landmark publication of Robert Hooke's Micrographia in 1665 prompted 18th century writers such as Jonathan Swift and Voltaire to employ changes of scale as a literary device. In the following century, George Eliot used microscopy as a metaphor in her greatest novel Middlemarch, and early 20th century novels by both H.G. Wells and D.H. Lawrence feature microscopy in key scenes. More recent examples of microscopy in literature have been harder to find.

$\begin{array}{ll}\text { Manuscript region of origin } & \text { Europe } \\ \text { Corresponding Author } & \text { Peter Harris } \\ \text { Order of Authors } & \text { Peter Harris } \\ \text { Suggested reviewers } & \text { Greg Lynall, Chris Hawes }\end{array}$

\section{Submission Files Included in this PDF}

File Name [File Type]

Endeavour Microscopy Highlights.docx [Highlights]

Endeavour Microscopy Harris.docx [Manuscript File]

To view all the submission files, including those not included in the PDF, click on the manuscript title on your EVISE Homepage, then click 'Download zip file'. 


\section{Microscopy and literature}

\section{Highlights:}

- $\quad$ Robert Hooke's Micrographia inspired 18th century writers such as Jonathan Swift and Voltaire.

- George Eliot repeatedly used microscopy as a metaphor in her novel Middlemarch.

- $\quad$ H.G. Wells and D.H. Lawrence both featured microscopy in their work.

- $\quad$ Contemporary writers should be encouraged to collaborate with scientists. 


\section{TITLE PAGE}

\section{Microscopy and literature}

Peter Harris

Electron Microscopy Laboratory, J.J. Thomson Building, University of Reading, Whiteknights, Reading RG6 6AF, UK.

Email: p.j.f.harris@reading.ac.uk

\section{Acknowledgements}

I want to thank Professor Steven Matthews for alerting me to the microscopy reference in The Rainbow, and thus giving me the idea for this article. In preparing the article I benefitted from listening to an episode of the BBC Radio 3 programme "Words and music" entitled "Under the microscope", broadcast on 5 Aug 2018, and I am also grateful to Laura Harris and Ian Harris for comments and suggestions. 


\section{Microscopy and literature}

Of all the Inventions none there is Surpasses

Ye noble Florentine's Dioptrick Glasses

For what a better, fitter guift Could bee

In this World's Aged Luciosity.

To help our Blindnesse so as to devize

A paire of new \& Artifical eyes

By whose augmenting power wee now see more

Than all the world Has ever Dounn before

In commendation of ye Microscope,

Henry Powers (1664)

On the face of it "Microscopy and literature" would seem an unpromising subject for an article. It would certainly be misleading to suggest that microscopes and microscopy have played a major role in English or European literature. However, when one begins to research the subject, many examples of microscopy in literature can be found. There is little doubt, for example, that the landmark publication of Robert Hooke's Micrographia in 1665 prompted $18^{\text {th }}$ century writers such as Jonathan Swift and Voltaire to employ changes of scale as a literary device. In the following century, George Eliot used microscopy as a metaphor in her greatest novel Middlemarch, and early $\mathbf{2 0}^{\text {th }}$ century novels by both H.G. Wells and D.H. Lawrence feature microscopy in key scenes. More recent examples of microscopy in literature have been harder to find.

It seems that the first use of the word "microscope" can be identified very precisely: it was coined by Giovanni Faber, a German doctor, botanist and art collector, on April 13, $1625^{1}$. A few years earlier, Galileo had developed a compound microscope which he named an occhiolino ("little eye"), but it was Faber's name that stuck. The most important figure in the early history of microscopy was the Dutch businessman and scientist Antonie van Leeuwenhoek, whose amazing work using single-lensed microscopes has been described in detail by Brian J. Ford ${ }^{2}$. However, it was the publication of Hooke's Micrographia in January 1665 (Fig. 1) that brought microscopy to the attention of the wider public. This beautiful book, the first to be published by the Royal Society, contained many stunning illustrations, such as the one shown in Fig. 2, and the first detailed drawings of a fly's eye and a plant cell. By the standards of the day, the book was a best-seller. One of the first to purchase it was Samuel Pepys. His diary entry for 21 st January 1665 concludes: "Before I went to bed I sat up till two o'clock in my chamber reading of Mr. Hooke's Microscopical Observations, the most ingenious book that ever I read in my life".
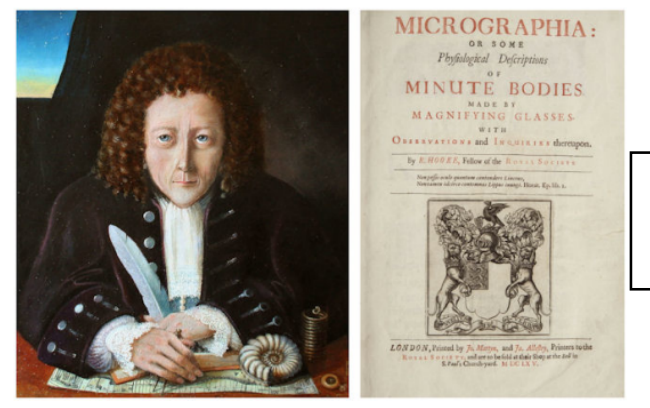

Figure 1. Robert Hooke (1635 - 1703), and the title page of Micrographia. 
It is a measure of the popularity of microscopy in the late $17^{\text {th }}$ century that it became a target for satire. Thomas Shadwell's play The Virtuoso (1676) ridicules modern science and the Royal Society, whose fellows are portrayed as spending their lives performing experiments of no practical use. The virtuoso of the title is Sir Nicholas Gimcrack, "a sot that has spent two thousand pounds on microscopes to find out the nature of eels in vinegar and mites in cheese has broken his brains about the nature of maggots . . and never cares for understanding mankind". Hooke attended a performance of the play and was mortified when he realised that the central character was based on him ${ }^{3}$.

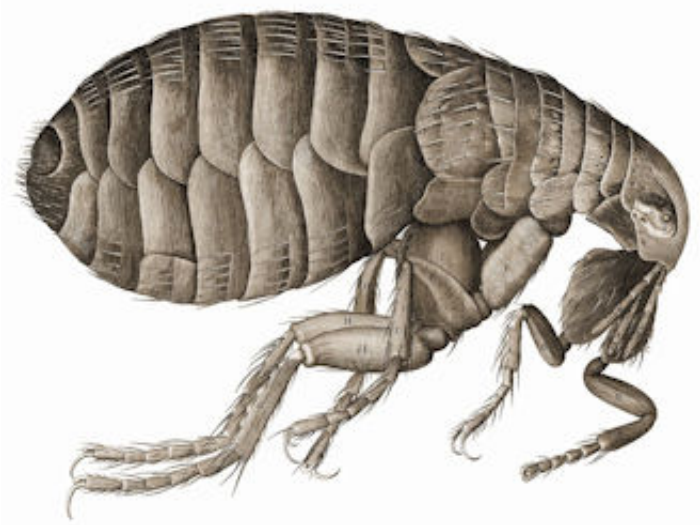

Figure 2. Hooke's drawing of a flea, from Micrographia (1665).

Another satirist who was undoubtedly influenced by microscopy was Jonathan Swift (Fig. 3). We know that Swift was familiar with Micrographia ${ }^{4}$, and that he bought a microscope for his wife Stella ${ }^{5}$. The influence of microscopy on Gulliver's Travels, published in 1726 (Fig. 4), has been discussed by a number of authors, notably Marjorie Hope Nicolson ${ }^{6}$. As Nicolson points out, rather than seeing the microscope as an exciting new window on nature, Swift seems to have been horrified by what the new instrument revealed. In "A Voyage to Brobdingnag", Gulliver finds himself in a land of giants. He thus becomes a becomes a kind of "human microscope" 6,7, able to discern with his naked eye the spots, pimples and freckles on the skin of the

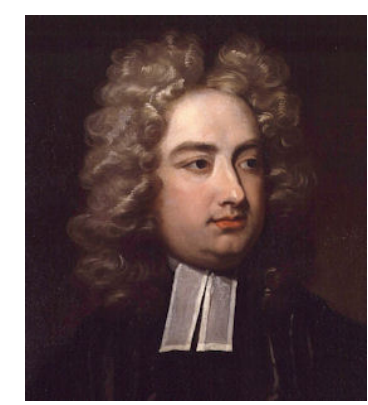

Figure 3. Jonathan Swift $(1667-1745)$. Brobdingnagians, and the lice crawling on their clothes in appalling detail. Swift's revulsion at what the microscope revealed is seemingly of a piece with his scepticism about the kind of

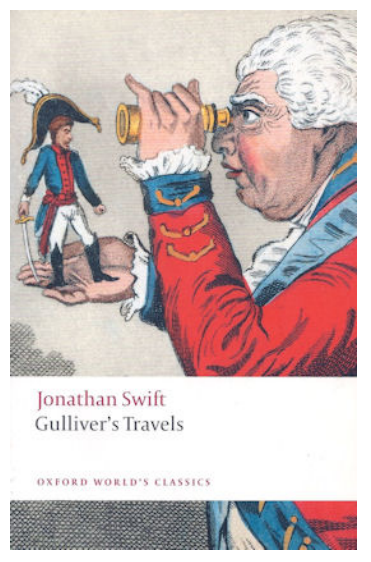

Figure 4. Gulliver's Travels by Jonathan Swift (1726). Cover of Oxford World's Classics edition showing cartoon by James Gillray. 
experimental science promoted by the Royal Society, something he shared with Thomas Shadwell (elsewhere in his Travels Gulliver encounters a scientist who has spent eight years unsuccessfully trying to extract sunbeams from cucumbers).

Swift was not alone in feeling uneasy about the heightened sensitivity which the microscope represented. Ann Jessie van Sant has pointed out that in Samuel Johnson's Dictionary (1755), the illustrative quotation for "microscope" (from a sermon by Richard Bentley) was as follows: "If the eye were so acute as to rival the finest microscopes, and to discern the smallest hair upon the leg of a gnat, it would be a curse and not a blessing to us." ${ }^{8}$. Alexander Pope's well-known lines from The Essay on Man (1733) also express a horror of "microsensation", as well as a scepticism about studying ever-smaller structures while missing the "bigger picture":

Why has not Man a microscopic eye?

For this plain reason, Man is not a Fly.

Say what the use, were finer optics giv'n,

T' inspect a mite, not comprehend the heav'n?

Or touch, if tremblingly alive all o'er,

To smart and agonize at ev'ry pore?

Less well known than Gulliver's Travels, at least in the English-speaking world, is Voltaire's 1752 novella Micromégas (Fig. 5). Considered one of the first true science fiction stories, this features a 450 year old, $37-\mathrm{km}$ tall alien with 1000 senses from a planet that orbits Sirius. He writes a scientific book examining the insects on his planet, which at $30 \mathrm{~m}$ in size are too small to be detected by ordinary microscopes. Micromégas' book is considered heresy, and he is banished from his home planet for 800 years. Eventually, with another giant from Saturn, he arrives on Earth. When he encounters the microscopic humans he initially assumes that they are too small to be intelligent, but eventually realises that human science and philosophy are the equal of his own. As Marc Olivier points out 9 “....... despite his physical advantages, he is subject to error, arrogance, and all other human shortcomings. This played well into the suspicion that new or augmented sense perception could not make us superior beings, despite the enthusiasm of some microscopists".
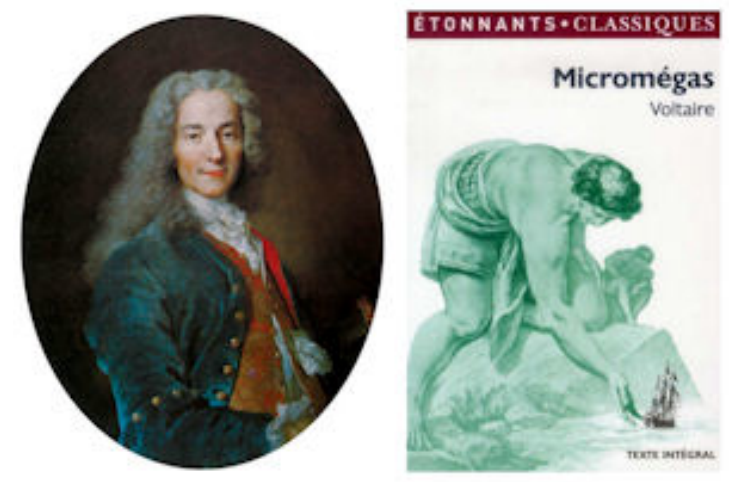

Figure 5. Voltaire (16941778), and cover of Micromégas (edition published by Flammarion).

It seems that microscopy as a science went into something of a decline following the early enthusiasm: Brian Ford has called the 1700s a "Lost Century" for the microscope ${ }^{10}$. This may have been partly because spherical and chromatic aberration limited further progress in resolving power. By the 19th century, however, the problems of aberration were largely solved and microscopy entered a new golden era. As well as improved microscopes, the development of histological dyes enabled cellular structures to be observed in more detail 
than ever before, and this led to huge advances in cell biology ${ }^{11}$. However the achievements of microscopists in the 19th century were not limited to biology. The invention of the polarizing microscope by Nicol in 1828, and its application to rocks by Sorby and others were of major importance in geology, while the discovery of Brownian motion by Robert Brown in 1827 had huge implications for physics. Unfortunately, despite these exciting developments, few of the great 19th century novelists showed much interest in microscopy. An exception was George Eliot (Fig. 6).

The specific role of microscopy in Eliot's life, and in Middlemarch (1872), which is widely regarded as her finest work, has been discussed in detail by Mark Wormald ${ }^{12}$. For many years, Eliot was in a relationship with George Henry Lewes, a polymath who counted microscopy among his many interests. Wormald believes that Eliot obtained an "intimate knowledge" of microscopy from Lewes, and that this explains the many microscopy references in Middlemarch. In the first of these references Eliot uses microscopy as a metaphor:

Even with a microscope directed on a water-drop we find ourselves making interpretations which turn out to be rather coarse; for whereas under a weak lens you may seem to see a creature exhibiting an active voracity into which other smaller creatures actively play as if they were so many animated tax-pennies, a stronger lens reveals to you certain tiniest hairlets which make vortices for these victims while the swallower waits passively at his receipt of custom. In this way, metaphorically speaking, a strong lens applied to Mrs Cadwallader's matchmaking will show a play of minute causes producing what may be called thought and speech vortices to bring her the sort of food she needed.

The Mrs Cadwallader referred to is a gossipy, interfering woman. What Eliot seems to be saying here is that it would be a mistake to take a simplistic/reductive view of this woman's behaviour, using "a weak lens". The "strong lens" of the microscope, however, reveals the complex sources of her motivation, exposing the minute intricacy of her manipulative games.

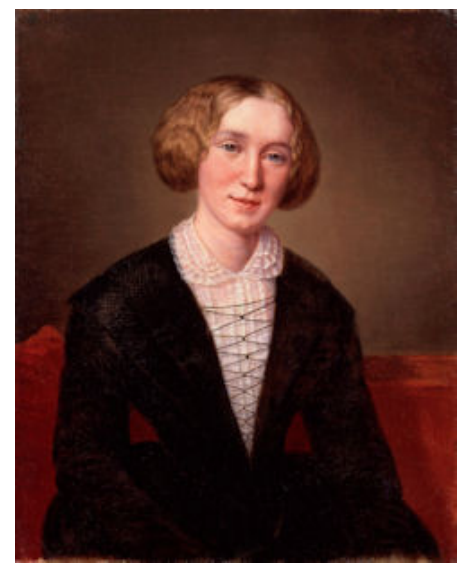

Figure 6. George Eliot (Mary Ann Evans, 1819 1880).

Later in the novel we are introduced to Tertius Lydgate, a doctor who uses a microscope to conduct medical research. He may have been partly based on Lewes ${ }^{12}$. At one point Lydgate gifts a copy of "Robert Brown's new thing" (the paper which described Brownian motion) to fellow microscopist Camden Farebrother, and, in a passage which echoes the metaphor quoted above, Lydgate lends Farebrother his superior microscope to examine some 'pondproducts", enabling him to see what he would miss were he using his own, "weaker lens" 13 . 
The influence of biology on Eliot's fiction is not limited to her discussions of microscopy. J. Hillis Miller has pointed out other examples which illustrate the "parallelism between Eliot's aim as a sociologist of provincial life and the aims of contemporary biologists" ${ }^{14}$.

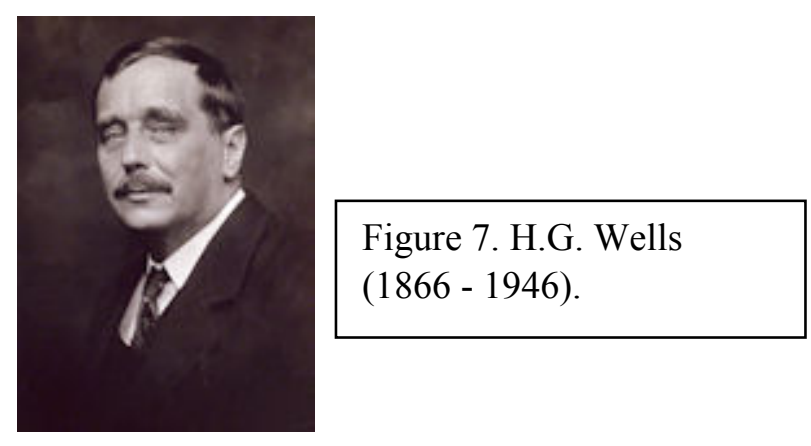

H.G. Wells (Fig. 7) is probably best known today for his pioneering science fiction novels such as The War of the Worlds (1898) but he was a prolific writer who worked in a number of different genres. Even his "non-science fiction" writing often involved science and scientists. The short story A slip under the microscope (1896) concerns the rivalry between two biology undergraduates called Hill and Wedderburn. They are competing for the highest marks in the final exam, as well as for the affections of fellow undergraduate Miss Haysman. The day of the exam arrives, and involves a practical test in microscopy. The demonstrator has placed a botanical section in the microscope, mounted on a glass slide (which Wells calls a slip), and positioned the specimen so that only part of it can be seen. Moving the specimen even slightly would reveal its identity. When it is Hill's turn disaster strikes.

Hill came to this, flushed from a contest with staining reagents, sat down on the little stool before the microscope, turned the mirror to get the best light, and then, out of sheer habit, shifted the slip. At once he remembered the prohibition, and, with an almost continuous motion of his hands, moved it back, and sat paralysed with astonishment at his action.

By shifting the specimen, Hill sees clearly that is a lenticel (a kind of porous tissue found in the bark of woody stems) but what to do?

His mind was full of this grotesque puzzle in ethics that had suddenly been sprung upon him. Should he identify it? or should he leave this question unanswered? In that case Wedderburn would probably come out first ........ How could he tell now whether he might not have identified the thing without shifting it? It was possible that Wedderburn had failed to recognize it, of course. Suppose Wedderburn too had shifted the slide?

Hill swallows his scruples and earns top marks in the exam. But his conscience troubles him and eventually he makes a clean beast of it with his professor. The unfortunate Hill ends up sent down from his college and greatly diminished in the eyes of Miss Haysman. We are left wondering whether he did the right thing in owning up.

Wells' highly enjoyable novel Ann Veronica (1909), describes how Ann Veronica Stanley, "a young lady of nearly two-and-twenty", struggles with the restrictions of a patriarchal society. She was "wildly discontented and eager for freedom and life". After a row with her father she leaves home and, with the help of a loan from a rich neighbour, Mr Ramage, enrols on a 
course in biology at the fictional "Central Imperial College" in London. Here she falls under the spell of the "exceptionally fair" demonstrator, Mr Capes. In a key passage, she moves from examining the specimen in her microscope to gazing yearningly at her tutor:

Then one day a little thing happened that clothed itself in significance.

She had been working upon a ribbon of microtome sections of the developing salamander, and he came to see what she had made of them. She stood up and he sat down at the microscope, and for a time he was busy scrutinizing one section after another. She looked down at him and saw that the sunlight was gleaming from his cheeks, and that all over his cheeks was a fine golden down of delicate hairs. And at the sight something leaped within her.

Here Ann Veronica's gaze seems to have become sensitised by microscopy (in a way that would have filled Swift with horror), so that she becomes acutely aware of the fine detail of Capes' face.

Unfortunately it turns out that Capes is married. To make matters worse, Ramage tries to take advantage of Ann Veronica, and she returns the money he lent her. With her prospects seemingly thwarted, Ann Veronica throws herself into the Suffragette struggle, and is sent to prison. She is appalled by the filthy conditions: "Horrible memories of things seen beneath the microscope of the baser forms of life crawled across her mind and set her shuddering with imagined irritations". Chastened, Ann Veronica returns to her father's home and agrees to get engaged to the hopeless Mr Manning, but soon realises she cannot live without Capes. So the pair, first brought together over a microscope, are finally united.

Another novel in which a female character experiences a kind of epiphany while operating a microscope is D.H. Lawrence's The Rainbow (1915). We know that Lawrence (Fig. 8) had read Ann Veronica ${ }^{15}$, and the similarities between Wells' heroine and Ursula Brangwen in The Rainbow are striking. Both are "New Women", looking for an independent path in life, and both study science at university. However, the consequence of Ursula's encounter with microscopy is rather different to that of Ann Veronica.

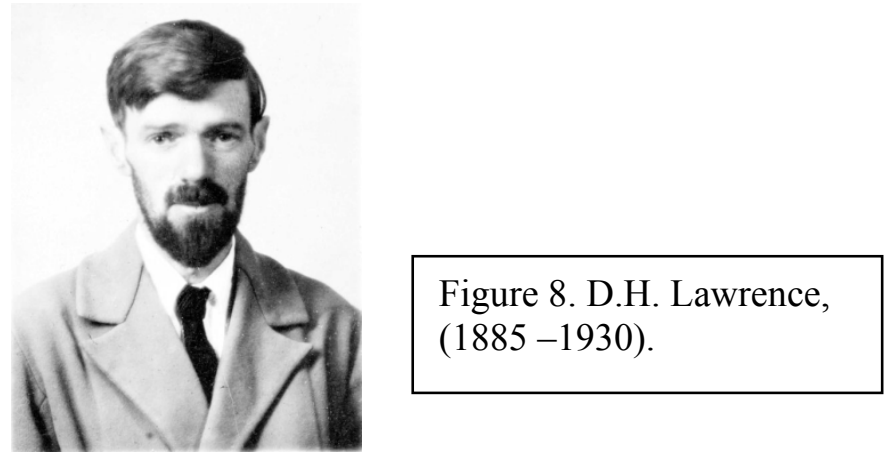

The Rainbow tells the story of three generations of the Brangwen family, farmers and craftsmen who live in Nottinghamshire. Ursula is a member of the third generation of Brangwens and comes of age in the early 1900s. While she is still at school she embarks on a love affair with Anton Skrebensky, a British soldier of Polish ancestry. After school she becomes a teacher, but struggles with a large class on unruly children. She goes on to university, but quickly becomes disillusioned with an institution which she sees as nothing more than a "factory" preparing students for industry. She is also at odds with the purely scientific, materialist view of life, put forward by her teacher, Dr Frankstone. How can she 
find meaning in her life? Then, while she is she examining a unicellular organism moving around under her microscope she has a revelation.

It intended to be itself. But what self? Suddenly in her mind the world gleamed strangely, with an intense light, like the nucleus of the creature under the microscope. Suddenly she had passed away into an intensely gleaming light of knowledge. She could not understand what it all was. She only knew that it was not limited mechanical energy, nor mere purpose of self-preservation and self-assertion. It was a consummation, a being infinite. Self was a oneness with the infinite. To be oneself was a supreme, gleaming triumph of infinity.

Viewing this tiny organism in the microscope, she becomes conscious of a universe beyond the humdrum everyday world of human society and convention. To be herself, with complete freedom, should be her aim in life. At the same time she realises that there is more to life than the materialist view proposed by Frankstone. There is a mystical aspect to existence, in which the individual is united with the infinite. In her new, independent state, she rejects Skrebensky's proposal of marriage, and at the very end of the novel the appearance of a rainbow after a storm represents an archway "through which Ursula may step to her unknown, open future" ${ }^{16}$. Ursula Brangwen's story is taken up in Women in Love (1920), but this later novel is regrettably free of any microscopy references.

A writer who had little success with microscopy was the American humourist James Thurber. His hilarious autobiography My Life and Hard Times (1933) includes a chapter "University Days" which describes his struggles. Thurber had poor eyesight, due to a childhood injury, and as a result could not see plant cells though his microscope. This enraged his professor: "“As God is my witness, I'll arrange this glass so that you see cells through it or I'll give up teaching. In twenty-two years of botany, I- '. He cut off abruptly for he was beginning to quiver all over, ....” (Fig. 9). Eventually Thurber adjusts the microscope so that he can see what he believes is a plant cell, but when the professor looks at his drawing he explodes: " 'That's your eye!' he shouted. 'You've fixed the lens so that it reflects! You've drawn your eye!'”. Thurber never did pass his botany course.

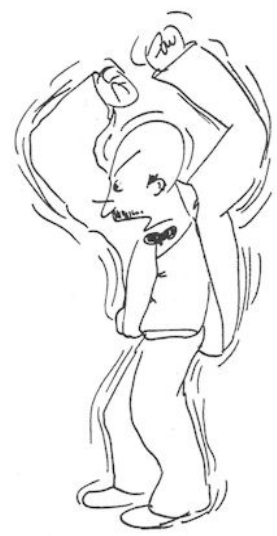

Figure 9. James Thurber's professor was enraged by his student's inability to use a microscope. Cartoon from My Life and Hard Times (1933).

It turns out, then, that there is more than enough material for an article on microscopy and literature. As we have seen, microscopy inspired the great $18^{\text {th }}$ century writers Swift and Voltaire, and was used as a metaphor or plot device by later authors including George Eliot, H.G. Wells and D.H. Lawrence. There are other writers who could have been discussed, such as Johann Wolfgang von Goethe, surely the only great literary figure to have carried out serious scientific research using a microscope ${ }^{17}$, or Ivan Turgenev, in whose 1862 novel 
Fathers and Sons, an avid microscopist, Bazarov, plays a major role. However, as noted above, there appear to be fewer recent examples of microscopy in literature, and I have found none which involve my own subject of electron microscopy. Possibly this reflects the professionalisation of today's science and the greater separation of the "two cultures". In the 18th and 19th centuries it seems that artists and scientists interacted much more closely than they do today, and science was practised as much by amateurs as by professionals. Thus, a writer like George Eliot could take time out from writing Middlemarch_by looking at biological specimens in George Lewes' microscope. By contrast, few contemporary writers will have experienced the wonders of modern microscopy. A few initiatives, such as LabLit (http://www.lablit.com/) have been set up with the aim of bringing writers and scientists closer together, and these should surely be encouraged.

\section{References}

1. Rochow TG, Rochow EG. Introduction to microscopy by means of light, electrons, $X$ rays, or acoustics. New York: Plenum; 1994, Chapter 1.

2. $\quad$ Ford BJ. The Leeuwenhoek legacy. Bristol: Biopress; 1991.

3. Inwood S. The man who knew too much: The strange and inventive life of Robert Hooke, 1635 - 1703. London: Pan; 2003.

4. Damrosch L. Jonathan Swift: His life and his world. New Haven: Yale University Press; 2013.

5. $\quad$ Crook K. A preface to Swift. London: Routledge; 1998.

6. Nicolson MH. Science and imagination. Connecticut: Archon; 1956.

7. Lynall G. In retrospect: Gulliver's Travels. Nature 2017; 549:454-456. DOI: 10.1038/549454a.

8. van Sant AJ. Eighteenth-century sensibility and the novel: The senses in social context. Cambridge: Cambridge University Press; 1993.

9. Olivier M. Binding the book of nature: microscopy as literature. History of European Ideas 31 (2005): 173-191. DOI: 10.1016/j.histeuroideas.2003.11.005.

10. Ford BJ. The revealing lens: Mankind and the microscope. London: Harrap; 1973.

11. Bradbury S. The evolution of the microscope. Oxford: Pergamon; 1967.

12. Wormald M. Microscopy and semiotic in Middlemarch, Nineteenth Cent. Lit. 1996; 50:501-524. DOI: 10.1525/ncl.1996.50.4.99p0191f.

13. British Library website page on "The Companion to the Microscope", https://www.bl.uk/collection-items/the-companion-to-the-microscope, accessed $11 / 12 / 18$ 
14. Miller JH. Optic and semiotic in Middlemarch. In Buckley JH, ed. The worlds of Victorian fiction Harvard: Harvard University Press; 1975:125-143.

15. Buckley M, Buckley B. Challenge and continuity: aspects of the thematic novel 18301950. Amsterdam: Rodopi; 2004 .

16. Flint K. Introduction to The Rainbow by D.H. Lawrence, Oxford: Oxford World's Classics; 1997.

17. Otto L. Goethe's four microscopes in Weimar, J. Microscopy 1975;106:71-83. DOI: 10.1111/j.1365-2818.1976.tb02385.x

\section{Figures}

High resolution versions of the illustrations for this article can be found here:

https://www.dropbox.com/sh/fdekz3bx6muq0ko/AACcThMS762NnCM0a3qB5RV0a?dl=0 